\title{
The effect of salinity on growth, photosynthesis and respiration in the estuarine red alga Bostrychia radicans Mont.
}

\author{
Ulf Karsten \& Gunter O. Kirst \\ Universität Bremen, Fachbereich Biologie: D-2800 Bremen, Federal Republic \\ of Germany
}

\begin{abstract}
The estuarine red alga, Bostrychia radicans, was subjected to osmotic stresses ranging from hypo-osmotic $(9.9 \%)$ to hyperosmotic conditions $(37.4 \%)$. The growth rate decreased with increasing salinities and showed a maximum in a mesohaline medium, while the photosynthetic rate and the chlorophyll a content increased under hyper-osmotic conditions. The rate of respiration remained constant over the salinity range tested. $B$. radicans revealed typical characteristics of "shade plants" having a low light compensation point at $3-4 \mu \mathrm{E} \mathrm{m}^{-2} \mathrm{~s}^{-1}$ correlated with a low photon flux density of $70-100 \mu \mathrm{E} \mathrm{m} \mathrm{m}^{-2} \mathrm{~s}^{-1}$ for saturation of photosynthesis. These physiological properties may explain the success of $B$. radicans in estuarine habitats.
\end{abstract}

\section{INTRODUCTION}

The red alga Bostrychia radicans Mont. (Ceramiales, Rhodomelaceae) is abundant in habitats with different salinities, i.e. in lagoons, in mangrove swamps, in freshwater and in many estuaries (Post, 1963a).

The algae, living in the upper eulittoral zone of estuaries are subjected to daily and seasonal changes of salinity due to the mixing of freshwater from the river with seawater, and the rise and fall of the tides (for review see Knox, 1986). For example, in the Mullica River estuary (New Jersey, USA) B. radicans tolerates a range of salinities between 5 and $30 \%$ (Yarish et al., 1979).

Based on its ability not only to survive but to grow and reproduce in various salinities $(5-35 \%)$, B. radicans was characterized as a "euryhaline" alga (Yarish et al., 1979). Photosynthesis of another species, $B$. binderi, showed little effect in a broad range of salinities between 10 and $40 \%$ (Dawes et al., 1978). In the same algae the effect of $\mathrm{Ca}^{2+}$, $\mathrm{HCO}_{3}{ }^{-}, \mathrm{NO}_{3}{ }^{-}$and $\mathrm{PO}_{4}{ }^{-3}$ on the photosynthetic rate under hyposaline conditions was tested (Dawes \& McIntosh, 1981). These nutrients elevated and stabilized the photosynthesis of $B$. binderi in extreme low salinities between 0 and $5 \%$.

It is obvious that Bostrychia must have physiological properties supporting the organism's salinity tolerance. The study presented here provides further and new data on growth, photosynthesis and respiration of $B$. radicans under various external salinities. 


\section{MATERIAL AND METHODS}

\section{Plant material and cultivation}

The estuarine red alga Bostrychia radicans Mont. obtained from the Göttingen Culture Centre, F.R.G., was cultivated in 500-ml beakers in aerated, artificial brackish water $\left(19.4 \%\right.$; prepared from synthetic sea-salt used for fish tanks; WIMEX ${ }^{\circledR}$, Wiegandt, Krefeld, F.R.G.) at $22^{\circ} \mathrm{C}$ illuminated with $30 \mu \mathrm{E} \mathrm{m}^{-2} \mathrm{~s}^{-1}$ (two $18 \mathrm{~W}$ daylight, Sylvana) and a light: dark cycle of $16 \mathrm{~h}: 8 \mathrm{~h}$. The media were enriched with $5.5 \mathrm{mM} \mathrm{NaNO}_{3}$ and $1 \mathrm{mM}$ $\mathrm{NaHCO}_{3}$. For all experimental procedures, algae were equilibrated to a range of hypoand hypersaline conditions $(9.9,19.4,28.9,37.4 \%$ ). The brackish water with the salinity of $19.4 \%$ will be defined as steady-state medium. Salinity was changed by increasing the $\mathrm{NaCl}$ concentration or dilution with distilled water. The final $\mathrm{NaHCO}_{3}$-concentration of the growth media was $3.5 \mathrm{mM}$. The plants were adapted step wise to the different salinities (5.1-6.8\% per day) and media were changed weekly over a 4 -week period.

\section{Physiological experiments}

Growth responses of the algae were determined weekly by fresh weight measurements estimated after standardized careful blotting with several layers of paper tissue. The relative growth rate $\mu$ was calculated from the initial $\left(W_{o}\right)$ and the final $\left(W_{t}\right)$ fresh weights of the algae using the equation:

$$
\mu=100\left(\log _{\mathrm{e}} \mathrm{W}_{\mathrm{t}}-\log _{\mathrm{e}} \mathrm{W}_{\mathrm{o}}\right) / \mathrm{t}(\mathrm{n}=4 \text { for each salinity). }
$$

Photosynthetic and respiratory rates were determined employing a Clark- $\mathrm{O}_{2}$-probe (YSI 53 ) in a temperature-controlled $\left(24^{\circ} \mathrm{C}\right)$ glass cuvette. Photon flux density (Schott quartz fibre with halogen lamp) was varied by adjusting the distance between cuvette and light source accordingly. Three replicates of each irradiance were used. The experimental media contained $4 \mathrm{mM} \mathrm{NaHCO}_{3}$; the temperature was $24^{\circ} \mathrm{C}$ and the $\mathrm{pH} 8.1-8.3$. To obtain saturated photosynthesis a photon flux density of $250 \mu \mathrm{E} \mathrm{m}^{-2} \mathrm{~s}^{-1}$ was applied. The $\mathrm{O}_{2}$ content of the different media was calculated according to Truesdale et al. (1955). Chlorophyll was extracted and concentrations of the algae were estimated according to Inskeep \& Bloom (1985).

\section{RESULTS}

An increase in salinity of the media was accompanied by a decrease in the relative growth rate $\mu$ (Fig. 1). Towards hyposaline conditions the growth rate increased linearly: there was a $95 \%$ decrease in growth between plants cultured in $9.9 \%$ to $37.4 \%$. Maximum growth of Bostrichia radicans at given conditions occurred at $9.9 \%$ representing a mesohaline medium.

B. radicans exhibited a low light compensation point at $3-4 \mu \mathrm{E} \mathrm{m} \mathrm{m}^{-2} \mathrm{~s}^{-1}$ and a saturation of photosynthesis between 70 and $100 \mu \mathrm{E} \mathrm{m}^{-2} \mathrm{~s}^{-1}$ (Fig. 2).

The respiratory and net photosynthetic rates of $B$. radicans cultivated under different salinities were measured after 4 weeks adaptation under conditions of light saturation $\left(250 \mu \mathrm{E} \mathrm{m}^{-2} \mathrm{~s}^{-1}\right)$ (Fig. 3). Photosynthesis changed with different levels of salinity. Under steady-state conditions $(=19.4 \%)$, a rate of photosynthesis of about $40 \mu \mathrm{mol} \mathrm{O} \mathrm{Ogg}^{-1}$ chlorophyll a $\mathrm{h}^{-1}$ was observed for $B$. radicans. The photosynthetic rate decreased with 


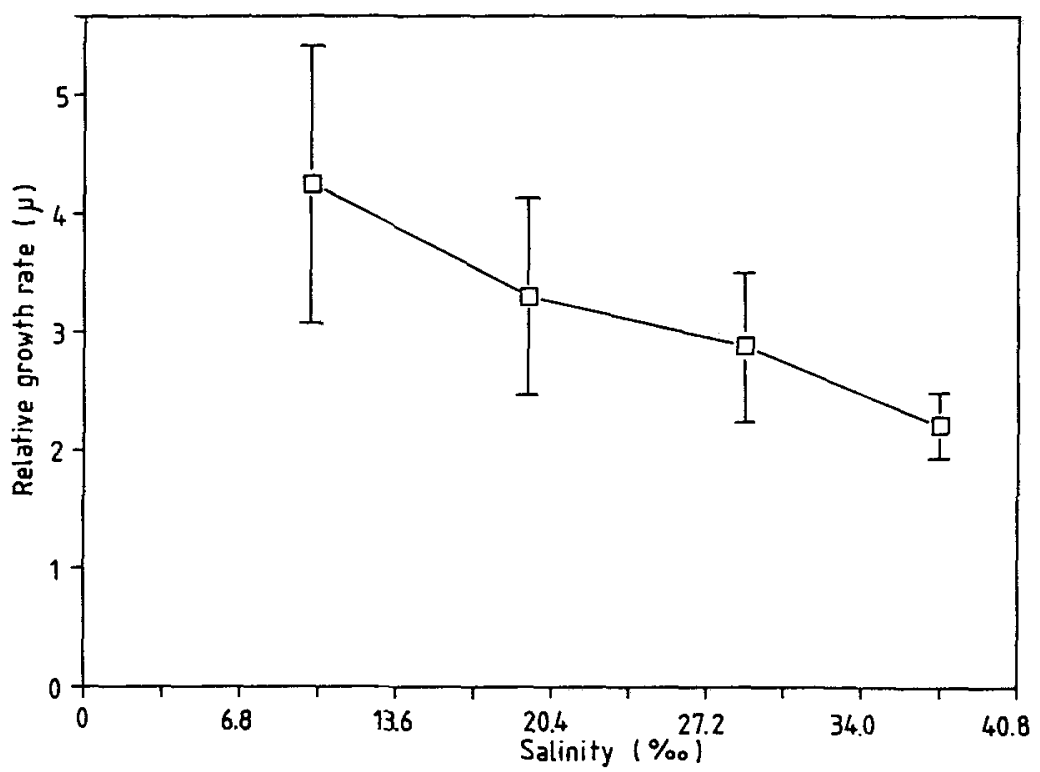

Fig. 1. Relative growth rate $\mu$ of Bostrychia radicans as a function of salinity. Data are expressed as mean \pm standard error $(n=4)$

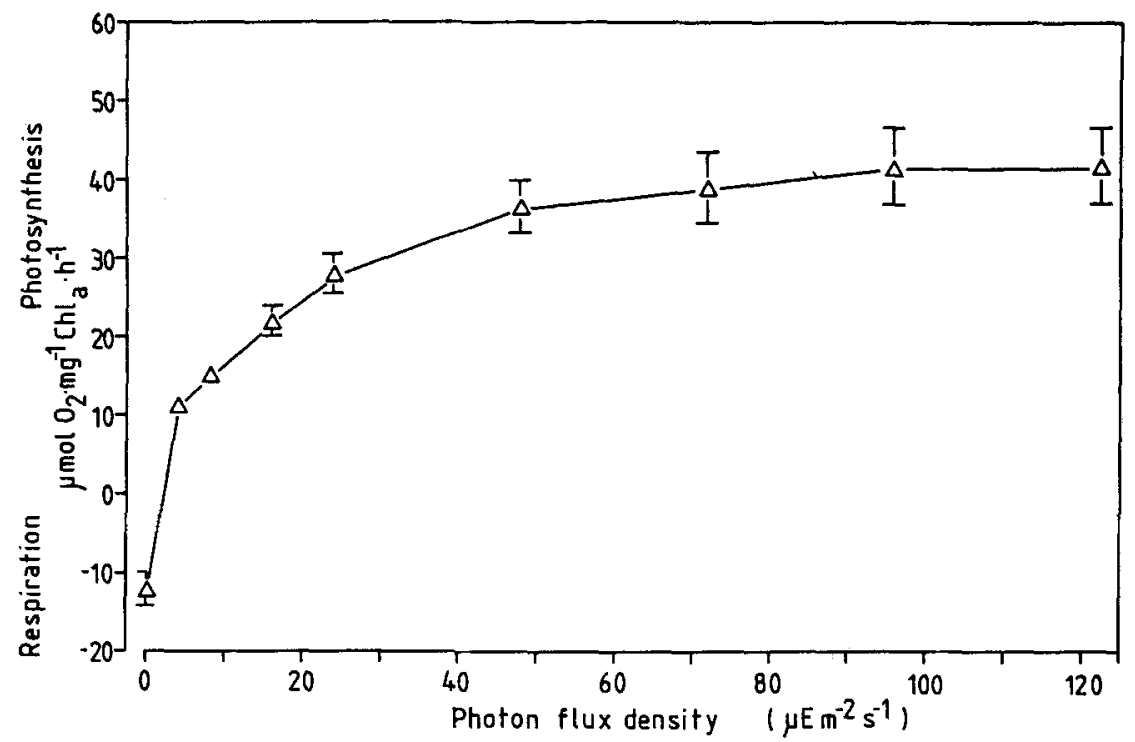

Fig. 2. Photosynthetic oxygen evolution of Bostrychia radicans grown at $19.4 \%$ as a function of photon flux density. Data are expressed as mean \pm standard error $(n=3)$ 


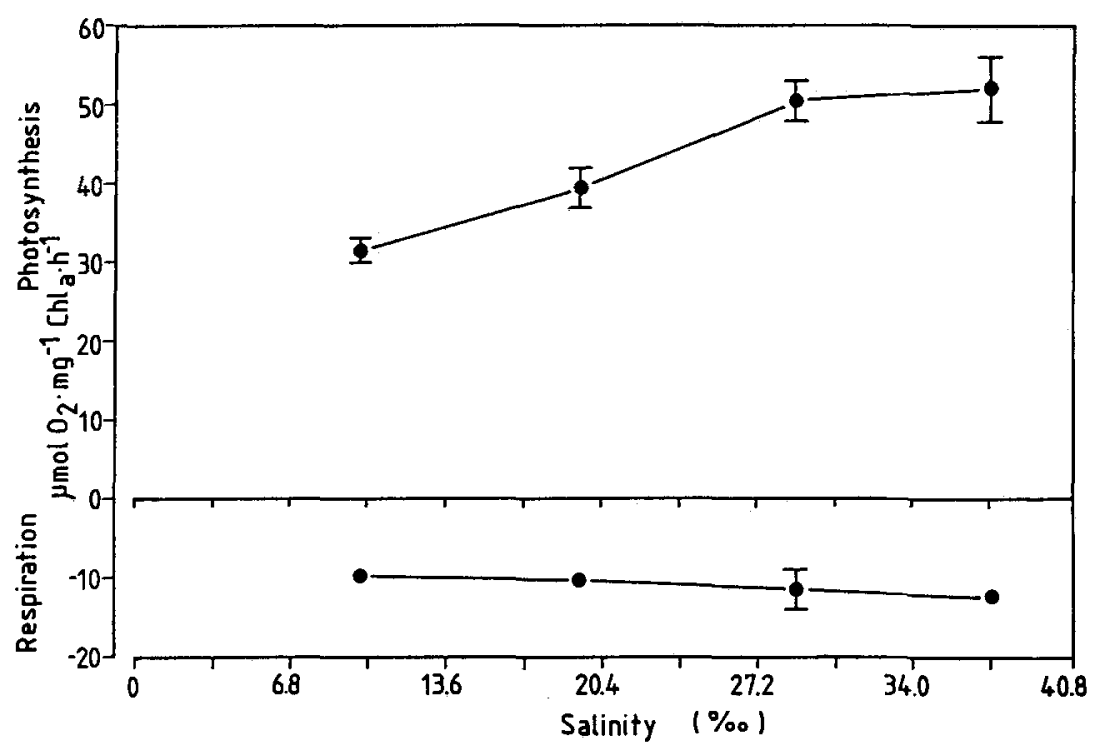

Fig. 3. Net photosynthesis and respiration rates of Bostrychia radicans grown under different salinities; measurement after 4 weeks adaptation. Data are expressed as mean \pm standard error $(\mathrm{n}=3)$

decreasing salinity $\left(9.9 \%: \approx 30 \mu \mathrm{mol} \mathrm{O} \mathrm{O}_{2} \mathrm{mg}^{-1}\right.$ chlorophyll a $\left.\mathrm{h}^{-1}\right)$, and was stimulated under hypersaline conditions, resulting in about $50 \mu \mathrm{mol} \mathrm{O}_{2} \mathrm{mg}^{-1}$ chlorophyll a h${ }^{-1}$ at $28.9 \%$. However, in the highest salinity tested $(37.4 \%)$ no further increase of the photosynthetic rate was observed. In contrast, the rate of respiration remained constant over the salinity range tested.

The chlorophyll a content of $B$. radicans was, under steady-state conditions $(19.4 \%)$,

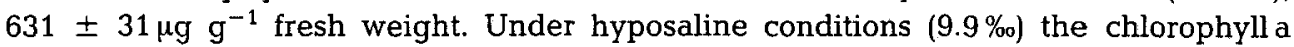
concentration decreased slightly to $590 \pm 10 \mu \mathrm{g} \mathrm{g}^{-1}$ fresh weight, while under hypersaline conditions, a linear increase in chlorophyll a content occurred. However, the increase was much more pronounced between 28.9 and $37.4 \%$ (826 $\pm 83 \mu \mathrm{g}$ chlorophyll a ${ }^{-1}$ fresh weight) compared with the results between 19.4 and $28.9 \%$ o (694 $\pm 32 \mu \mathrm{g}$ chlorophyll a $\mathrm{g}^{-1}$ fresh weight). A rise in chlorophyll a content of about $30 \%$ was observed over the experimental range of salinities.

\section{DISCUSSION}

Under hypersaline conditions the growth response (Fig. 1) was in agreement with the results of Yarish et al. (1979), who investigated ecotypes of Bostrychia radicans, their growth pattern being correlated with the salinity regime in their natural habitat. One isolate of $B$. radicans showed optimal growth at $15 \%$, the others between 15 and $25 \%$. In contrast, algae investigated in this study exhibited maximum growth under hyposaline conditions in a mesohaline medium $(9.9 \%)$. Therefore, it is assumed that this isolate represents a separate ecotype.

The low light compensation point $\left(3-4 \mu \mathrm{E} \mathrm{m}^{-2} \mathrm{~s}^{-1}\right)$ together with a low photon flux 
density for saturation of photosynthesis $\left(70-100 \mu \mathrm{E} \mathrm{m}^{-2} \mathrm{~s}^{-1}\right)$ (Fig. 2) characterized $B$. radicans as a typical "shade-plant" (Raven et al., 1979). This agrees with the usual conditions in their natural habitat: Post (1963b) described the alga as a plant preferring shaded and protected sites on rocks or banks such as crevices and cavities. When exposed to higher photon flux densities $\left(>100 \mu \mathrm{E} \mathrm{m}^{-2} \mathrm{~s}^{-1}\right)$, B. radicans became green indicating photo damage, and the growth was inhibited.

The increase in chlorophyll a content with increasing salinity is well documented for microalgae (Al-Hassan et al., 1987), but a satisfactory explanation is still lacking.

The rhodophytes are equipped with typical accessory pigments including the phycobilins (Lüning, 1985; Wilhelm et al., 1987), which represent an efficient light-harvesting system, and which may explain the low light compensation point of $B$. radicans. In the red alga Griffithsia monilis Harvey the phycobilins are the major light-harvesting pigments under low light intensities, whereas with increasing photon flux density, carotenoids and chlorophylla contribute proportionally more (Larkum \& Weyrauch, 1977). B. radicans is very likely to respond in a similar manner as G. monilis. Ogata \& Matsui $(1965 \mathrm{a}, \mathrm{b})$ investigated the photosynthesis of different Japanese marine algae. In nearly all plants, the maximum photosynthetic rate was found in normal marine habitat, and photosynthetic depressions were observed both in diluted and in concentrated sea water. In contrast, the photosynthetic rates of the red alga Porphyra purpurea (Roth) C. AG. subjected to quasi-estuarine salinity fluctuations was shown to decrease and increase in a synchronous manner (Reed et al., 1980). The increase of the photosynthetic rates of $B$. radicans under hypersaline conditions $(28.9$ and $37.4 \%)$, and the decrease of the photosynthetic rate under hyposaline conditions $(9.9 \%$ a) were similar. The enhanced photosynthetic rate under high salinities after 4 weeks of culture can partly be explained by the increase in the chlorophyll a content. It seems that the photosynthetic process of $B$. radicans under these conditions was functioning more effectively. However, in most algae investigated photosynthesis was inhibited under short-term as well as long-term hyperosmotic stresses (Kirst, 1981; Reed, 1983; Wright \&' Reed, 1985; Kirst \& Wichmann, 1987). The inhibition of the photosynthesis is most likely due to changes in the fine structure of the chloroplasts (Wiencke, 1982) causing a disruption of energy transfer between the two photosystems.

Gessner \& Schramm (1971) emphasized the ecological importance of the time span of exposure to reduced or increased salinities and the speed with which a given change here photosynthesis - is effected.

$B$. radicans subjected to a sudden hyperosmotic shock responded with only a little inhibition of photosynthesis and respiration (data not shown) compared to other macroalgae such as $G$. monilis (Kirst, 1981). After severe changes in salinities from 19.4 to $45.9 \%$, photosynthetic rates were inhibited to about $24 \%$, the respiratory rates to about $2 \%$ only. In contrast, Ogata \& Takada (1968) reported considerably decreased intensities of respiration in the red alga Ceramium sp. in very low and very high salinities, whereas Wiencke \& Davenport (1987) showed a stable respiration in Cladophora rupestris (L.) Kütz. under fluctuating salinity regimes. As observed in other species of macroalgae, respiration of $B$. radicans was much less affected compared to photosynthesis e.g. Lamprothamnium papulosum (Wallr.) J. Gr. (Kirst \& Wichmann, 1987). In conclusion, photosynthesis and respiration of $B$. radicans under long-term as well as short-term hypersaline conditions appear to be relatively insensitive to osmotic stresses. This, and 
the broad growth pattern may assure survival in the estuarine habitats as described in the introduction.

\section{LITERATURE CITED}

Al-Hassan, R. H., Ghannoum, M. A., Sallal, A. K., Abu-Elten, K. H. \& Radwan, S. S., 1987. Correlative changes of growth and lipid composition of Dunaliella salina in response to halostress. - J. gen. Microbiol. 133, 2607-2616.

Dawes, C. J., Moon, R. E. \& Davis, M. A., 1978. The photosynthetic and respiratory rates and tolerances of benthic algae from a mangrove and salt marsh estuary: a comparative study. Estuar. coast. mar. Sci. 6, 175-185.

Dawes, C. J. \& McIntosh, R. P., 1981. The effect of organic material and inorganic ions on the photosynthetic rate of the red alga Bostrychia binderi from a Florida estuary. - Mar. Biol. 64, 213-218.

Gessner, F. \& Schramm, W., 1971. Salinity. In: Marine ecology. Ed. by O. Kinne. Wiley Interscience, New York, 1 (2), 705-820.

Inskeep, W. P. \& Bloom, P. R., 1985. Extinction coefficients of chlorophyll a and b in N,N-dimethylformamide and $80 \%$ acetone. - Pl. Physiol. 77, 483-485.

Kirst, G. O., 1981. Photosynthesis and respiration of Griffithsia monilis (Rhodophyceae): effect of light, salinity, and oxygen. - Planta 151, 281-288.

Kirst, G. O. \& Wichmann, F., 1987. Adaptation of the euryhaline Charophyte Lamprothamnium papulosum to brackish and freshwater: photosynthesis and respiration. - J. Pl. Physiol. 131, $413-422$.

Knox, G. A., 1986. Estuarine ecosystems: A systems approach. CRC Press, Boca Raton, Fl, 1, 1-36.

Larkum, A. W. D. \& Weyrauch, S. K., 1977. Photosynthetic action spectra and light-harvesting in Griffithsia monilis (Rhodophyta). - Photochem. Photobiol. 25, 65-72.

Lüning, K., 1985. Meeresbotanik: Verbreitung, Ökophysiologie und Nutzung der marinen Makroalgen. Thieme, Stuttgart, $383 \mathrm{pp}$.

Ogata, E. \& Matsui, T., 1965 a. Photosynthesis in several marine plants of Japan in relation to carbon dioxide supply, light and inhibitors. - Jap. J. Bot. 19, 83-98.

Ogata, E. \& Matsui, T., 1965b. Photosynthesis in several marine plants of Japan as affected by

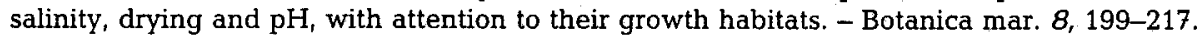

Ogata, E. \& Takada, H., 1968. Studies on the relationship between the respiration and the changes in salinity in some marine plants in Japan. - J. Shimonoseki Coll. Fish. 16, 67-88.

Post, E., 1963 a. Zur Verbreitung und Ökologie der Bostrychia-Caloglossa-Assoziation. - Int. Revue ges. Hydrobiol. 48, 47-152.

Post, E., 1963b. Bostrychia - nicht tot zu kriegen. - Botanica mar. 5, 9-18.

Raven, J. A., Smith, F. A. \& Glidewell, S. M., 1979. Photosynthetic capacities and biological strategies of giant-celled and small-celled macro-algae. - New Phytol. 83, 299-309.

Reed, R. H., Collins, J. C. \& Russell, G., 1980. The influence of variations in salinity upon photosynthesis in the marine alga Porphyra purpurea (Roth) C. Ag. (Rhodophyta, Bangiales). - Z. PflPhysiol. 98, 183-187.

Reed, R. H., 1983. The osmotic responses of Polysiphonia lanosa (L.) Tandy from marine and estuarine sites: evidence for incomplete recovery of turgor. - J. exp. mar. Biol. Ecol. 68, 169-170.

Truesdale, G. A., Downing, A. L. \& Lowden, G. F., 1955. The solubility of oxygen in pure water and sea-water. - J. appl. Chem. 5, 53-62.

Wiencke, C., 1982. Effect of osmotic stress on thylakoid fine structure in Porphyra umbilicalis. Protoplasma 111, 215-220.

Wiencke, C. \& Davenport, J., 1987. Respiration and photosynthesis in the intertidal alga Cladophora rupestris (L.) Kütz. under fluctuating salinity regimes. - J. exp. mar. Biol. Ecol., 114, 183-197.

Wilhelm, C., Krämer, P. \& Wiedemann, I., 1987. Die Lichtsammelkomplexe der verschiedenen Algenstämme. - Biol. unserer Zeit 17, 138-143.

Wright, P. J. \& Reed, R. H., 1985. The effects of osmotic stress on intracellular hexitols in the marine brown alga Himanthalia elongata (L.) S. F. Gray. - J. exp. mar. Biol. Ecol. 93, 183-190.

Yarish, C., Edwards, P. \& Casey, S., 1979. A culture study of salinity responses in ecotypes of two estuarine red algae. - J. Phycol. 15, 341-346. 